\title{
INVESTIGATION OF GENETIC VARIABILITY IN NATURAL DROSOPHILA POPULATIONS *
}

The paper describes the origin and development of population genetics, its main discoveries achieved in experiments with Drosophila before 1948 breakage and summarized the resutts of two series of long-term studies on genetic variability in Drosophila carried out by the authors. The conceptual contribution of two main centers or school leadet by N. Koltzos and S. Chetverikov in Moscow and Yu. Filipchenko in St.-Petersburg is coissidered. The ideas and methodology of these schools were introduced into American and Etropean genetics by Th. Dobzhansky and N. V. Timofeev-Ressovsky.

$A$ new approach to the description of the eukaryotic genome organizations is described. The authors argued that main source of the origin of various hereditary changes in nature is the interaction of environment with the facultative genomic elements.

Biological background and the origin of genetics. At the beginning of our century, biology in Russia was llourishing. It is noteworthy to mention here that I. P. Pavlov in 1904 and I. I. Mechnikov in 1908 were Nobel prize winners. Leading Russian biologists traditionally were initrested in evolutionary problems [1]. In his comprehensive review Vucinich [110] correctly concludes that Russian scientists «alone represented the full spectrum of attitudes and critical stances toward the scientific, sociological and general intellectual merits of the Darwinian theory of evolution». Even an idea as popular in modern cellular and evolutionary biology as symbiogenesis was conceptually developed firstly by Russian botanists but almost completely ignored in the West [74].

Russian evolutionary thought developed through dynamic discussion and often controversy. One group of evolutionists accepted and contributed widely to Darwinian theory. Among them were the eminent Russian zoologists - brothers Alexander and Vladimir Kovalevsky, Menzbir, A. N. Severtzov and his follower I. I. Schmalhausen, Dogel, Zavarzin, Shimkevitch, botanists Komarov, Sukachev, Taliev, Tsinger.

At the same time there were the eminent critics of the main concepts of Darwinian theory. The most illustrious embryologist of the pre-Darwinian period, Karl von Baer $(1792-1876)$, a distinguished member of the St. Petersburg Academy of Sciences was one such critic. We may also include here the famous botanists: Korzhinsky who discovered, simultaneously with Hugo de Vries, mutations in plants, and also Faminisyn, Borodin. The great zoologist Lev Berg (the father of a famous population geneticist Raissa Berg) developed the impressive anti-Darwinian conception of Nomogenesis. His book was translated into English and issued in the 1960 s as a second edition with a preface by Th. Dobzhansky. More recently Dobzhansky [20] characterised this book as «marshalling an abundance of evidence comparable to Darwin».

With this intellectual background the appearance and flourishing of population and evolutionary genetics seem preadapted. Two main centers or ohools of general and population genetics were set up in Moscow and Petersburg (Leningrad). Some branches of this genealogical roots are shown in Appendix. In Moscow an eminent biologist N. K. Koltzov (1872-1940) organised the Institute of Experimental Biology. According

* The paper is dedicated to the memory of Theodosius Dobzhansky.

C) M. GOLUBOVSKY, L. KAIDANOV, 1994 
to Dobzhansky [20] Koltzov was «a man of multifarious interests and knowledge, of imposing presence, and with the eloquence of a spellbinding orator. His public lectures were events memorable to his peers and to beginners alike». In 1921 he invited in his institute S. S. Chetverikov (1880-1959) and A. S. Serebrovsky (1892-1949) to develop the field of genetical studies. Their disciples make up the famous Moscow school of evolutionary and population genetics $[2,5,20,65,109]$.

Chetverikov conducted regular evolutionary seminar series named «Droz-So-Or» literally translated by Adams [2] as «the combined cacophony of drosophilists» or more loosely «the drosophilist screeching society». The restricted membership of this informal seminar which was conducted as Chetverikov's home was mutual sympathetic [18]. Chetverikov's students were B. L. Astaurov, E. I. Balkashina, N. K. Belyaev, S. M. Gershenson, P. F. Rokitsky, D. D. Romashov, N. V. Timofeef-Ressovsky, Helene A. Fiedler (then Timofeef-Ressovsky's wife). Other biologists attended the seminar: Koltzov himself, A. S. Serebrovsky and his students V. V. Sacharov, N. P. Dubinin. Serebrovsky's own Drosophilists included the eminent scientist Zoya $\mathrm{S}$. Nikoro (she collaborated then with Chetverikov since middle 30 s up to 1948) and also N. I. Shapiro and R. B. Khesin, who combined in the 70 s to molectlar, general and populational genetics.

N. I. Vavilov (1887-1943) and Yu. A. Filipchenko (1882-1930) were leaders of the Leningrad (St. Petersburg) shool of evolutionary and population genetics. In 1921 Vavilov headed the Institute of Applied Botany (later the Institute of Plant Industry). He succeeded in collecting a cohort of an outstanding scientists. Among them were famous cytogeneticists G. A. Levitsky and G. D. Karpechenko, both of which together with their leader Vavilov, were killed during Stalin's reign of terror. Levitsky studyed the structure of the chromosome from the point of view of systematics and evolution. He coined the term «karyotype». Curiously, namely Levitsky, originally the professor of botany in Kiev accidentally met there, the graduate student Dobzhansky (he rented the room at flat of Levitsky) and attracted him to genetics.

In 1913 Filipchenko began teaching the first course in genetics in Russia at Petersburg University. He then formed the Department of Genetics and Experimental Zoology (1919) and later in 1921, the Laboratory of Genetics in the Russian Academy of Sciences. With the sudden death of Filipchenko in 1930, Vavilov became the director of this laboratory. In 1933 it was moved to Moscow and transformed into the Institute of Genetics. Vavilov headed the institute up to his arrest in 1940.

Filipchenko was a brilliant biologist combining both a profound knowledge of general biology and the history of evolutionary though with vast experimental skills. His interests in genetics range from plant genetics to eugenics. He wrote six textbooks $[30,31]$ and many reviews which, according to Dobzhansky [20] were used in institutions of higher learning «until Lysenko's pogrom». Filipchenko had great impact on the evolutionary and genetical thought in Russia. He was the first person who clearly distinguished between micro and macroevolution.

Dobzhansky was an assistant professor in Filipchenko's department between 1924-1927. Many famous Russian geneticists graduated from Filipchenko Department: Yu. Ya. Kerkis, A. A. Prokofieva-Belgovskaya, M. L. Belgovsky, N. N. Medvedev, I. A. Rapoport, M. E. Lobashov and Raissa Berg.

The ideas and methodology which developed in these Russian shools were introduced into European genetics by Timofeev-Ressovsky. His dramatic biography and scientific life were recently reviewed [88]. Certain traditions of Russian shool were transferred to America by Dobzhansky. Both emigrants are renown in their fields and together helped found the new discipline of population genetics.

Major contributions before 1948. Before embarking on a detailed description of Russian studies on the field of population and evolutio- 
nary genetics of Drosophila let tus try to discriminate between these two related fields. Evolutionary genetics embraces the analysis of the organisation of genetic material, its comparison in different species and mechanisms of change, phenomenology of the expression of genetic factors, genetical aspects of speciation and events of intra and interspecies hybridization. Population genetics includes first of all an analysis of genetic heterogeneity and the polymorphism of populations together with the mechanisms responsible for its maintenance, the study of the genetic consequences of selection and other evolutionary forces, genogeography and the phenetics of natural populations.

Hugo de Fries could well be named the father of evolutionary genetics. He rediscovered Mendel's laws of inheritance of genetic variants. He established the principles of the spontaneous mutation process. He described polyploidy and chromosomal speciation in Oenothera and he found non-mendelian peculiarities in the progeny of interspecies hybrids.

An the same time $\mathrm{S}$. S. Chetverikov contributed to the foundation store of both theoretical and experimental population genetics. In his classical paper $[16,17]$ he published important conceptual discoveries. He introduced the concepts of mutation pressure and genotypic milieu. He described material, methodology and tasks of population genetics. He linked the concepts and data of mendelian genetics with the theory of natural selection and ontogenesis. He also made important theoretical predictions which were consequently confirmed by his students. From the point of theory of knowledge and cognitology it was a real conceptual discovery [90].

Using the inbreeding method, Chetverikov's students established the predicted existence of hidden recessive mutations in the progeny of wild flies of different Drosophila species [36, 94, 104]. Following on, Dubinin and his collaborators used the method of homozygotisation of autosomes of $D$. melanogaster with the help of dominant balanced markers (a modification of Muller's classical approach). Dubinin and his group conducted a systematic comparative analysis of the concentration of lethal mutations in geographically remote populations. During 11 years of study they described the lethal and visible mutation frequency in 14 populations. The study produced the first reliable data set allowing a comparison of the genetic load of drastic mutations from distant populations $[23-25]$.

The results obtained by Dubinin's group were confirmed by other population investigators from the Leningrad school $[12,86,87]$. Similar data were also obtained both on $D$. melanogaster and other Drosophila species in United States in the well known studies of Dobzhansky, Gordon, Ives and Spencer. Gershenson succeeded in carrying out simultaneous «isogenisation» of all autosomes of $D$. melanogaster in a sample of flies caught from a wild population. This approach revealed that practically every fly from nature carried some mutations. This fact permitted a more accurate evaluation of genetic heterogeneity in natural populations and gave a better insight into the mechanism of interaction between mutations located in different chromosomes.

The description of minor or physiological mutations distributed in natural populations was made simultaneously by Dobzhansky and Queal [21] and Muretov [85]. The talented young including the ideas of penetrance, expressivity and specificity. In addition, Rokitsky [92] introduced the concept of a «field of gene action» or a stereotyped pattern of gene expression through studying inherited Drosophila bristie variations. All of these components or modules of a gene manifestation may be under the influence of genotypical and external factors.

Timofeev-Ressovsky $[105,106]$ also conducted a series of obvious and simple experiments showing that the combination of two or three drastic mutations may increase variability. The methodology of this investigation was used by Dobzhansky in his classical studies on the effect 
of lethal mutations isolated from nature and on the viability of their heterozygous carriers.

Some of the major contributions made by Russian studies to the field of Drosophila population genetics are presented in Table 1 .

The Russian biologist I. I. Schmalhausen classically associated with the field of evolutionary morphology developed the theory of stabilising selection. He was deeply involved in the study of evolutionary and population genetics. He was also the supervisor to the Doctor of Science degree for both $M$. M. Kamshilov and Raissa Berg. At the end of 30 s he invited to his Institute in Kiev, a brilliant geneícist, S. Gershenson.

Under the influence of Schmalhausen, Kamshilov completed a series of sophisticaled experiments on the evolution of norms of reaction. He showed that the morphological manifestation of a mutation and the mode of its expression after developmenlal action of different external factors can be compleiely transformed during natural selection. For instance, the mutation eyeless in $D$. melanogaster originally having quite a variable expression may be readily transformed by selection into a developmentally stable form $[69,70]$.

Kamshilov also modelled the physiological effects and genetical adapfation of poptulations to drastic external factors. Populations of flies were selected for tolerance to severe cold temperature treatment. After a successful result, it appeared that the action of weak cold treatment during development became a stimulating factor [71]! Thus, the conditions of selection are indirectly imprinted into the genotypically based norms of reaction with selection changing the role of different genes during de-

Table i

Major contritations of Drosophilists to the field of population genetics before 1948

Contribution

Author, year

A. Conceptual fiscoveries and ideas

The conceptual basis of population genetics: concepts of mutation pressure» genotypical milieu; direction of studies The concept of gene pool and genogeography

The concept of genetic drift of «automatic genetical processes»

The principles of phenotypical realisation of the genotype: penetlltance, expressivity and specificity

The cylogenetical principles of population pest control

\section{B. Experimental discoveries}

Evidence for mutation heterozygosity in natural populations of different Drosophila species

The high concentration of recessive lethals in wild popur lations and differencies between them in their lethal gene pool content

Inversion polymorphism in wild populations, its adaptive value and temporary fluctuations

A detailed description of minor viabilty mutations spreading in natural populations

The viability advantage of some natural lethals in heterozygotes

The genotypical control of mutability; the discovery of highly mutable genes in natural populations

Transformation during selection, phenotypically or physiologically expressed norms of reaction

$A$ synchronous rise and fall of mutability level in geographically isolated populations

Chetverikov [16]

Serebrovsky $[95,96]$

Romashov [93],

Dubinin [22]

Timofeev-Ressovsky

$[103,105,106]$

Serebrovsky [98]

H. A. and N. W. Timo-

feev-Ressovsky [104],

Romashov, Balkashina,

[94], Gershenson, [36]

Dubinin et al. [25],

Dubinin [23]

Dubinin and Tinyakov

$[26,27]$

Muretov [85]

Mazing [81]

Tinyakov [105],

Gershenson [38],

Berg et al. [12],

Berg $[6,7]$,

Duseeva [28]

Kamshilov [69, 71]

Berg et aI. [12],

Berg [6, 7] 
velopment and their contribution to resulting phenotype. Unfortunately the original works of Kamshilov practically disappeared becoming the unknown and unquoted predecessor to some of Waddington's major experiments and ideas.

One of the major problems studied in Filipchenko's Department was the genetics of specialion and interspecies hybridisation. The possibility to investigate this problem arose when Sturtevant discovered the species $D$. simulans which is the sibling to $D$. melanogaster. After reviewing the long history of such studies, Provine [91] concluded that, after Sturtevant, «primary among these were the studies of Julius Kerkis of the Laboratory of Genetics, USSR Academy of Sciences in Leningrad». Kerkis (1907-1977) was involved in genetics with Dobzhansky after their curious accidental meeting in a forest near Kiev in 1920 . Kerkis was then a boy collecting butterflies and Dobzhansky was a student collecting la'dy-birds. Later they met again in Filipchenko's Deratment in Leningrad. Kerkis became a student of Dobzhansky's and friend until death. Kerkis conducted remarkable experiments on the influence of temperature on the hybrids [72] and described the character of conjugation of polytene chromosomes hybrids [73].

Profound jdeas in the fields of evolutionary and population genetics were developed by Serebrovsky $(1892-1948)$. He proposed the concept gene pool andof the gene pool and genegeography [96, 97]. In 1929 he was the first, together with his student Dubinin, to deduce the complex linear structure of the scute-achaete locus. Modern molecular data confirmed their principal conclusion, mentioning «the pioneering work of the Russian genetic school in the 1930s» [15]. Then in 1938 Serebrovsky, summarising data on the genetical study of scute-achate locus, came to the profound conclusion that new genes arise in the process of evolution via the process of duplication and divergence. This idea was also ahead of its time and that of Ohno's.

The dramatic fate of the other original idea of Serebrovsky's about usage of induced translocations for insect pest control is aiso now known [98]. The paper rested in obscurity till 1968. In 1968 Serebrovsky's paper was resurrected by C. F. Curtis and then an English translation was disseminated throughout western literature. In 1941 Serebrovsky prepared a more detailed version of his paper «Theoretical foundations of the translocation method of pest control» which was not published until 1971. The impact of Serebrovsky's ideas on a conceptual basis for genetical control was thoroughly analysed by Whitten [111].

One of the peculiar achievements of Chetverikov's school is the synthesis of data from population genetics and developmental genetics [5]. Timofecf-Ressovsky established the main principles of the morphological manifestation of mutant genes.

Thus Russian population genetics developed constantly in productive union with evolutionary morphology. It corresponds that there is current interest in the phenotypically or physiologically expressed traits of organisms. As noted sarcastically by Scharloo [95] «after the Dark Age of Elektrophoresis, evolutionary biologists are now experiencing the Renaissance of the Phenotype».

The direction of 'studies during the modern period. After Lysenko's pogrom in 1948 all genetical studies in the USSR ceased. They were renewed only in the 1960's in three main centres: (1) The Institute of Developmental Genetics in Moscow headed by B. L. Astaurov, an eminent evolutionary geneticist from Chetverikov's group; (2) The Department of Genetics in St. Petersburg (Leningrad) University, headed by $M$. E. Lobashov from Filipchenko's school and (3) The Institute of Cytology and Genetics organised in 1957 in Novosibirsk Academic City (Academgorodok). The first director of Novosibirsk Institute was Dubinin. He invited there Julius Kerkis and Zoia S. Nikoro who collaborated with Chetverikov from the mid 30s up to 1948. In 1963 Raissa Berg headed the first laboratory of population genetics at The Novosibirsk Institute where she 
renewed her long term studies on mutability in natural Drosophila populations.

We briefly summarise some of the main results obtained after the 1960's.

The dependence of inversion polymorphisms on ecological factors discovered initially in $D$. funebris populations by Dubinin and his associates was confirmed by Borisov [14] following his studies of $D$. funebris populations in the Moscow region. The existence of urban and rural races of Drosophila differing in karyotype structure was confirmed together with established evident spreading of the rural race over a 20 year period from 25 to 800 square kms.

A remarkable series of experiments on interspecific hybridisation among the $D$. virilis group was conducted by N. N. Sokolov and his followers. Sokolov [100] developed an exact cytogenetical method of chromosome substitution for the study of nucleocytoplasmic incompatibility for interspecies hybrids. He showed that in the hybrids of $D$. virilis $\times D$. lummei somatic heteroploidy regularly occurs due to the elimination of one chromosome in the first of the mitotic cleavage division. Then Evgeniev showed that the elimination of this chromosome from one species is result of presence of $A-T$ rich region and its retarded replication.

Mitrofanov $[83,84]$ continued the phenogenetic tradition of the Moscow school of evolutionary genetics. He found that penetrance of dominant Puffed mutation, which is located on the 2nd chromosome of $D$. virilis, rreatly varied in intraspecies hybrids, depending on the origin of the wild strain and the presence and concentration of modifier genes. In interspecies hybrids the expression of Pf was shown to be influenced by cytoplasmic factors.

Evgenjev and Zelentzova [29] described a new family of mobile elements in $D$. virilis group called $\mathrm{pDv}$. In $D$. virilis individual copies of pDv are scattered over approximately 200 sites on all chromosomes. In other related species $D$. texana and $D$. novamexicana, the number of $\mathrm{pDv}$ sites is markedly lower, where the pDv copies are completely absent in $D$. littoralis. Localisation of $\mathrm{pDv}$ coincides with the sites of concentrati. on of satellite DNA. In interspecific hybrids of $D$. virilis $\times D$. littoralis and $D$. virilis $\times D$. lummei transposition of $\mathrm{pDv}$ from $D$. virilis chromosomes to foreign ones was demonstrated. These data can be used to explain the drastic reshuffling of stDNA in $D$. virilis and other related species. Movable elements mav well be functioning as a shuttle svstem.

Evgenjev and Lozovskaya afterwards discovered the phenomenon of hybrid dusgenesis in $D$. virilis connected with the mobilisation of $\mathrm{Pdv}$ and the occurrence of unstable mutations.

Korochkin and his associates [77] has been conducting comprehensive comparative genetic and hiochemical analysis of the expression of a clusters of esterase genes in different philades of Drosophila. Thev found that species-specific differences in the expression and developmental regulation of esterase genes are connected with the action of regulatory mutations. They discovered and localised different types of trans-acting reoulators or modifiers which are selected during evolution. These include (a) regulators controlling isozyme activity and the amount of mRNA, (b) temporal regulators which control the exact time of tissue-specific expression and (c) «architectural» genes controlling the ratio of free and membrane bound fractions. These result may be presented as the molecular incarnation of the above mentioned phenogenetic concepts of Timofeev-Ressovskv and Rokitsky.

An exclusively important and original set of data were obtained by a Russian Drosophilists on the problem of the origin of spontaneous mutations. As early as 1939. Gershenson 1371 discovered the mutagenic action of foreign DNA in Drosophila. These promising studies were interrupted firstly be war and then by the collapse of Russian genetics in 1948. Since the 1960s Gershenson, together with his follower Yu. N. Alexandrov, undertook a systematic study of the peculiar mutagenic action 
of this natural source of variation. It was established $[39,40]$ that foreign DNA extracts, including DNA and RNA viruses added to Drosophila food or injected in haemolymph, raised the mutation rate and produced an unstable state of some host genes. The action of toreign and viral DNA and RNA differed in their locus specificity. Autosomal lethal mutations and unstable visible ones occurred preferentially in a definite group of loci characteristic for each foreign agent tested.

Multilocus damages, which result in so called multi-lethal chromosomes, have been observed regularly. On the other hand multi-lethal chromosomes were isolated in distant natural populations [41]. Is it possible that the damage caused by multi-lethal chromosomes from nature is induced by viral foreign DNA?

The possibility of an experimental approach to solve this problem appeared after the creation of two types of lethal collections: (a) lethals induced by viruses and exogenous DNA by Yu. N. Alexandrov in the laboratory of Gershenson and (b) lethals isolated in different years from distant natural $D$. melanogaster populations. The authors decided to compare the allelic sets of lethals from these two collections [3]. In became apparent that multilethal chromosomes from natural populations showed allelism with lethals induced by different viral DNA. Together with data collected by Golubovsky and Plus [53] it follows that (a) viruses may be a specific source of spontaneous mutations and (b) during virus-induced mutagenesis in nature similar multiple chromosome lesions can occur repeatedly and independently in isolated populations as a result of a single mutation event.

There are additional pieces of evidence towards this conclusion. Firstly, that foreign viral agents may activate different host mobile elements and induce unstable mutations [33]. Secondly, that multiple chromosomal lesions occur during $P$ and Hobo-mediated hybrid dysgenesis $[13,68,78]$.

The main conclusion from Gershenson's discovery is important. Gershenson constantly stressed that if we bear in mind how universally distributed viruses are, how often human beings come into contact with them after various prophylactic virus inoculations and when virus preparations are applied in the struggle against harmful insects, etc, then we have to recognise that the mutagenicity of viruses is a very serious problem $[40]$.

Another important conclusion was made by R. B. Khesin (19221985) - the last outstanding disciple of Serebrovsky. He published [75] o comprehensive volume, «Genome Inconstancy» where he collected and thoroughly analysed, from an evolutionary point of view, all data sets from viruses to high eukaryotes concerning mobile elements and about mobility of other genomic elements (amplification, ordered rearrangemenis during development etc.). He put forward the idea that the eukaryotic genome must be viewed, as a population of self reproducing DNA and RNA molecules. Moreover, having in mind the regular horizontal transfer of transposons and plasmids in microorganisms, the increasing number of similar facts in Drosophila species and the occurrence of the same retroviral sequences among remote animal species, Khesin concluded that it is possible to conceive of a gene pool encompassing all living organisms [75]. Thus Serebrovsky's gene pool concept exhibits an unpredictable and colourful array. The search for the source of genetic variability in nature leads to the study of the interaction between different DNA and RNA carriers and logically to biocenotic genetics (the synonym of biocenosis in western literature is ecosystem).

Biocenotic genetics has being distinct aspects. One of them was deveioped in the Department of Genetics of St. Petersburg University [79, $80 \mathrm{j}$. In the ecological system Drosophila melanogaster-Saccharomyces cerevisiae Drosophila is a consuming species and the yeast is a producing species. Drosophila and yeast are linked through the food chain in natural biocenoses: Drosophila shows an obligate dependence on sterol 
biosynthesis of yeast. Sterols are required by insects as the buildings blocks of membranes and as precursors of ecdysone. The steroid hormones control larval moults and metamorphosis. Luchnikova and Inpe-Vechtomov decided to study the effect of a genetic block in the synthetic pathway of the producing organisms on the genetic variation of the consuming one. Mutant yeasts deficient in sterol biosynthesis were used. The feeding of Drosophila larvae on the mutant yeast blocked larval development. Starving adult flies of sterols shortens their lifespan and decreases fertility $i$, e. the rates of oviposition and subsequent hatching. In addition female become sterile. The genetic consequences of the mutational alteration in the yeast-Drosophila food chain are an increased rate of induced mutations in flies (aneuploidy, dominant lethals) and a decreased frequency of crossingover.

Long-term population studies on Drosophila. Now we are starting on our own series of long-term experiments with Drosophila connected with the genetic analysis of natural populations and the analysis of the genetic consequences of selection. As noted by Dobzhansky [19], there are only a handful of cases in which genetical changes in populations were actually observed. The need for such studies on Drosophila after the discovery of global changes in the genetic structure and distribution of movable elements and after evidence of their recent horizontal transfer, are now becoming even more necessary [76]. Long-term systematic studies of natural and laboratory populations yielded some unpredictable and un. clear results.

Survival strategies of inbred long-selected lines: gen tic me $\mathrm{ch}$ a $\mathrm{n}$ is $\mathrm{m}$ s. The evaluation of the genetic consequences of selection is a very important task for population genetics and the theory of selective breeding. To approach this problem, a long term experiment was conducted in 1965 . Flies from a $D$. melanogaster natural population collected from Yessentuki (Crimea) were selected for low mating activity in males by close inbreeding [63]. As a result, a low activity strain (LA) with a complex of morphological, physiological, behavioural and genetic alterations, which greatly decreased its fitness, was established [66]. In the LA strain the whole spectrum of changes probably resulted from a correlated response to negative selection for an adaptively important trait.

Up to 1993 the LA stock had been selected for 650 generations. The aim of this long term experiment was to study the nature of genetical variability in response to different generations of inbreeding and to establish the genetic mechanisms that promote survival in inbred lines under strong selection. Three main mechanisms were discovered:

(1) a highly increased level of mutability in inbred stocks and the accumulation of supervital mutations capable of suppressing lethals and semilethals; the maintenance of a high potential for genetic variability;

(2) the non-accidental ordered transpositions of some copialike mobile elements accompanied with increased viability;

(3) mediated by Hobo-elements, a considerable increase in genome instability of lines selected in the minus-direction.

The manifestation of the first mechanism was demonstrated by successful reverse selection of flies from the LA stock in a plus direction. The possibility of successful selection in the plus and minus dircctions after many dozens or even hundreds of inbred generations demonsirates the high potential for hereditary variation in the strains studied. IIsing the standard $C y L / P m$ procedure, we found in LA second chromosomes the whole spectrum of mutations from lethal to supervital one. The proportion of various classes of mutations was repeatedly estimated during the selection protocol $[64,67]$.

In the HA strain which was selected simultaneously for high mating activity, the genetic load was minimal, whereas in the LA strain nearly $50 \%$ of 2nd chromosomes carried deleterious mutations. A considerable proportion of chromosomes in the highly active strain carried supervital 
mutations. This finding is consistent with comparisons of strains selected in the opposite direction.

By recombinational analysis we have demonstrated the presence of supressor mutations in the HA (high activity) inbred stock. The half-dominant and dominant supressor mutations can be viewed as elements of a compensation complex according to Strunnicov [99].

The study of behaviour of different movable elements in inbred stocks was accomplished in collaboration with V. A. Gvozdev and his colleagues in the Institute of Molecular Genetics of Russian Academy of Sciences (Moscow). The distribution of movable elements $m d g 1, m d g 3$ and $m d g 4$ and copia was studied in the original inbred stocks and its derivatives selected in both plus and minus directions. Distinct interstrain differences were found with respect to the number and localization of mig copies. The original strains were quite stable over many years. Transposition frequencies of $m d g$ elements according to rough estimates are close to $1 \cdot 10^{-4}$.

The directed familial selection for increased adaptive properties resulted in the segregation of certain rare families with an increased adaptive capacity. It turns out that in these families the genome is reconstructed: $m d g$ elements appear at new sites and their number generally increases. Copies usually vanish from old sites but in some cases a proportion of them may remain at their previous locations.

It has been demonstrated for the first time that this type of genome restructuring involves a large number of $M E$ s operating synchronously. The copies of MEs in new sites often appear together. The genome presumably contains «hot spots» that are targets for highly effective transposition of MEs during selection for increased fitness. In the LA strain the number of mdgI movable elements was minimal. But in the substrains with increased viability from one to seven new sites of $m d g l$ appeared. At least two mobile genes, mdg 3 and copia, have an affinity to similar chromosomal regions. This leads to the conclusion that their transposition is coordinated. Such trends have not been observed for other mdg families. Copies of the mdg4 family never change their localisation in response to selection.

Gvozdev and Kaidanov [61] have put forward a hypothesis concerning the existence of a system of adaptive transpositions of $M E s$ which is based on the regulatory effect of MEs on the array of structural genes. The long terminal repeats of copia-like MEs contain both termination sites and enhancers. This gives them the capacity to regulate the gene.

Lethal mutations occurred in LA stocks at a high frequency. Some LA chromosomes with an apparent lethal mutation were maintained as $C y L /$ lethal heterozygotes in a balanced condition for nearly three years. Then they were screened for their disposition of mobile elements and for the presence of rearrangements. The result was striking. A considerable number (13 of 33 or $39,4 \%$ ) of lethal containing chromosomes carried chromosomal rearrangements, predominantly paracentric and pericentric inversions. Most of the rearranged chromosomes (9 out 13) carried a combination of several inversions, and among them two also had transpositions and one a franslocation. Apparently in crosses of $C y L / P m$ strains to LA, the induction of complex multisite rearrangements had taken place. They strongly resemble those appearing in crosses which induce $H-E$ hybrid dysgenesis due to the transposition of hobo-elements [78]. It appears that one of the LA substocks contained about $30-35$ copies of the hobo-element on all of its major polytene chromosome arms.

In addition to rearrangements the letha! chromosomes maintained in balancers ( $C y L /$ lethal) showed an enormous level of mass transposition. In lethal chromosomes of LA strains less than $30 \%$ of the original sites of copia-like movable elements contain original disposition [68]! Such reshuffling of the genome is presumably the result of the activation of Hobo-elements capabie of inducing hybrid dysgenesis. 
The discovery of the ordered or concerted transposition of mobile genetic elements made it necessary to re-evaluate earlier conventional views about the non-directional nature of hereditary variation. We probably have to recognise that selection can control the formation of pattern of migration of mobile elements in the genome Hot spots of the genome are targets which quickly become occupied by mobile genes when selection is directed towards intensification of vital functions $[61,65,68]$.

Long term-studies of gene pool dymaics, mutation outbursts, and gene instability in Drosop h il a p op ulation s. Long term studies conducted since 1963 by Golubovsky and his associated resulted in a number of major conclusions:

(1) the existence of parallel and synchronous changes in the gene pool in adjacent and distant natural populations of $D$. melanogaster;

(2) the discovery of ubiquitous stable polymorphisms of the oncogenic lethal mutation $l(2) g l$-lethal (2) giant larvae;

(3) evidence that mutation outbursts in nature are connected with the appearance of unstable mutations and the activation of an mobile elements results in insertions and transpositions.

(4) a new understanding of the eukaryotic genome's organisation and the nature of spontaneous hereditary changes.

Dobzhansky and his colleagues have described synchronous fluctuations in the frequency of defined inversions in distinct populations of $D$. pseudoobscura $[4,19]$. Parallel results were found during long term studies on mutability and the dynamics of gene pools of lethals and visible mutations $[7,9-11,46,49]$. Up to beginning of the 60 s certain general features concerning the population concentration of recessive lethals and their allelic content were established. But what was needed was a detailed description of the population dynamics of the lethal pool and an estimation, in statu nascendi, the influence of the major microevolutionary factors (i. e. the mutation process, selection, drift, isolation etc).

Toward this it was decided to analyse the dynamics of the lethal gene pool (concentration, allelism and localization) simultaneously in two to three adjacent populations together with a genetic analysis of the geographically most distant ones. Populations from Uman were choosen (Ukraine, between Kiev and Odessa) because they had been initially studied by Berg and Olenov in the $30 \mathrm{~s}$. About 40000 diallelic crosses were carried out and the fate of more than 100 letha! genes on 2 nd chromosome was investigated. Comparisons of the patterns of lethality were made between the different seasons of fly reproduction (the beginning of spring, summer and the end of autumn) and in successive years.

We found two peculiar features of lethal pool dynamics: (a) a quasistationary state, and (b) parallelism in dynamics and allelic content of lethals in adjacent populations. The concentration of lethals accumulated in heterozygotes was stably maintained in each population studied at a defined level. Allelism tests of intrapopulation samples $(40-50$ lethal containing chromosomes on average) showed that nearly half of the lethals sampled occurred singly, while other lethals were pereated, being represented by two, three or more alleles. Each year there was a considerable turnover of the gene pool on account of the transition of rare (unique) lethals to the category of repeated ones and vice versa... hence the term quasistationary state.

Meanwhile a systematic and simultaneous comparison of lethal sets in adjacent populations revealed remarkable parllelism despite the constant allelic turnover. Allelic sets of lethals from different populations studied in the same season usually showed greater similarity than sets of lethals extracted in successive periods from the same population. No mutation process and no genetic drift can explain such parallelism.

It has been suggested that the quasistationary state and parallel changes in allelic lethal content is a consequence of hostparasite selection with the possible tolerance of flies carrying some lethals in hetero- 
zygous condition to infectious microorganisms $[8,49]$. The lethal alleles giving relative tolerance to their carrier provide a selective advantage as long as they are relatively rare. But after spreading in populations flies carrying such repeated lethals lose their advantage when new mutations of virulence appear in the infectious agent. The similar ordered flow of lethal alleles is thereby ensured in different host fly populations [49].

This picture of permanent turnover of the gene pool of lethals is complemented by the remarkable ubiquitous stable polymorphism of lethal alleles of the gene $l(2) g l$-lethal giant larvae (or simply $l g l$ ).

The ubiquitous distribution of $l(2) g l$ alleles in natural populations of Ukraine, Crimea, Middle Asia and Far East was demostrated in two periods: 1963-1978 [43-45], and then in 1979-1989. Hundreds of genes are capable to mutate to the lethal condition on the 2nd chromosome of $D$. melanogaster and it is namely $\lg l$ alleles that mutate most frequently. We observed that each fly out of $20-50$ is $+/ \lg l$ in nature. What is the reason for their ubiquitous distribution? It was found that $+/ l g l$ animals have an advantage in stressful conditions: the action of cold or high temperature during development and infection of virulent picornavirus DCV $[89,101,102]$.

During the middle of 60 s Elisabeth Gateff made a fascinating discovery that blockage of metamorphosis in $\lg l$ homozygotes is due to invasive neoplastic growth of brain tissue cells. It appears that $\lg$ is the first example of a monogenically controlled neoplasm in Drosophila and the first case of a tumor-supressor gene found in animals [32].

Phenogenetic analysis of $l g l$ alleles extracted from different populations showed their multiple allelism. So we are not dealing here with the single mutation having arisen once and then spread, but with a continuous mutation process at a given locus following selection of newly arisen lethal alleles [101]. This conclusion was confirmed by the molecular analysis of natural lgl alleles made by Bernard Mechler who showed that all lethal $\lg l$ alleles are intragenic deletions and insertions [82]. The same "roo» or B104 movable element is inserted in lgl locus in distant populations. At the same time Green and Shepherd [59] found that $\operatorname{lgl}$ mutations are also frequent in a Californian population and that the $\operatorname{lgl}$ gene is the target of the action of a powerful $M R$ mutator factor. In the presence of MRh-12 microdeletions in the telomeric region of the left arm of 2 nd chromosome, where $\lg l$ is located, originate with a frequency of $10^{-3}$.

Thus it turns out that the selective gene in natural populations is itself capable to regulate the level of its mutability, maintaining in a population its specific mutator. From a general point of view it is essential to note that lethal oncogenic mutations may provide a heterozygous selective advantage. Can we exclude a similar situation occurring in humans where several tumor-supressor mutations have also been discovered (human neuroblastoma is very similar to neuroblastoma induced by $l(2) g l$ alleles $)$ ?

$A$ third aspect of the long-term studies of genetic variability in natural populations concerns the montoring of the mutation process. The concept of specific periods during which the mutation rate sharply rises was first developed by Hugo de Vries but subsequently rejected. Longterm population studies definitely support this old idea. Particularly demonstrative are outbursts of mutability at the same loci observed practically simultaneously in distant populations. In 30 s Russian population geneticists found high mutability in the sex-linked genes yellow and white $[6,7,28,38]$. Afteh the $40 \mathrm{~s}$ the mutability of yellow and while returned to a normal level [7]. From the beginning of $80 \mathrm{~s}$ the mutability level of the yellow gene in the Uman population once more sharply increased. But this time the «fashionable» alleles were not yellow ${ }^{1}$ but yellow ${ }^{2}$ $[56,117]$.

In summary, the authors, up to 1973, have accumulated much experimental cvidence for what they have called the phenomenon of «Mode of 
Mutations». They predicted that one definite mode «will pass giving way to other visible anomalies》 [49]. This proved to be the case. Namely in 1973 in two geographically isolated populations (Caucasus and Middle Asia region) an outburst of mutability of the sex-linked singed bristle 'locus was discovered $[10,62]$. The sn mutability increased a hundred fold to $(0,3-0,9) \cdot 10^{-3}$. The peculiar thing about this mutation mode was the simultaneous appearance of multiple superunstable alleles in distant populations and the fact that not only the mutant but their normal derivatives are quite unstable.

The detailed genetic analysis of unstable sn-alleles lead to the conclusion that instability of the sn-gene is the result of insertions $[42,50$,
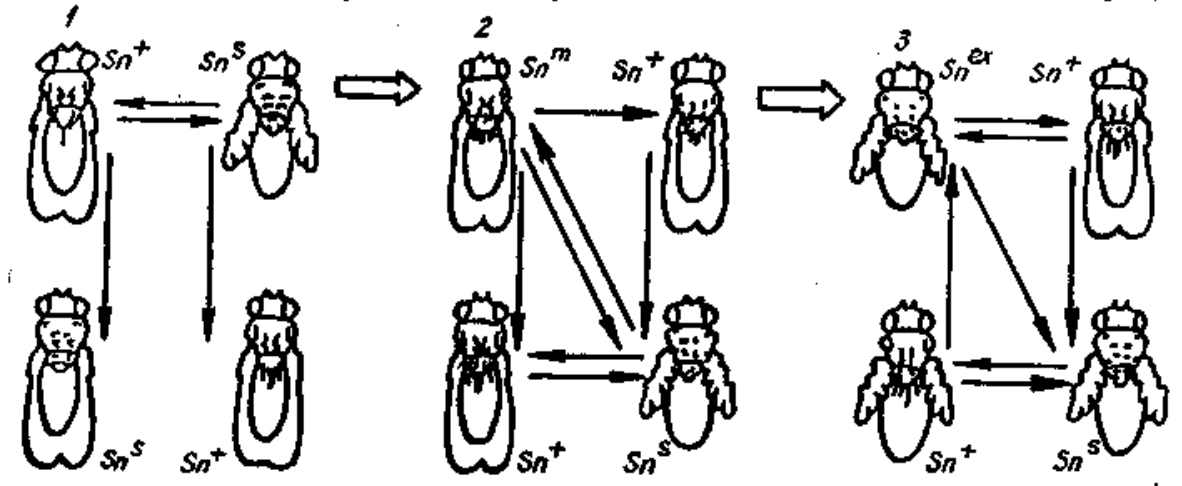

Fig. 1. Natural genetic engineering. Transposon loading by two mutations in the $\mathrm{X}$-chromosome isolated from a Far East population. The two genes sn-singed bristles and $c / w$-club wing concomiantantly manifest and form one bimutant unstable system. Symbols $s n^{+}, s n^{\mathrm{m}}, s n^{\mathrm{s}}$ and $s n^{\mathrm{ex}}$ correspond to the phenotypes wild, moderate, strong and extreme mutant bristle. Arrows point to the direction of mutations of a given allele. A scheme shows that mutation transitions are ordered in three clusters 1,2 . and 3 . Ciusters differ by phenotypes of $s n$-unstable derivatives, the direction and frequency of their mutation transitions and the character of concomitant c/w manifestation. Inside of each cluster the rate of mutations is evormous, up to $2-5 \%$ in average. Transitions between clusters are quite rare $\left(10^{-4}\right)$ and connected with the appearance of a new $s n$ allele. In clusters $I$ and $?$ sn-alleles mutate according to the principle «all or none» in both directions. But: (i) in cluster $l$ c/w phenotype manifest only concomitantly with sn-mutant expression and $s n^{+}$always $\mathrm{c} \boldsymbol{w}^{+} ;$(ii) in cluster $3 \mathrm{c} / w$ manilests both in $s n^{e x}$ and $s n^{+}$derivatives $[112]$

571. The behaviour of the unstable $s n$-gene was quite similar to the behaviour of the unstable mutation studied by $B$. McClintock. Thus her remarkable hypothesis about the existence of movable controlling elements appeared to be valid not only for maize and for some laboratory alleles in Drosophila but also for natural Drosophila populations. At Stadlers' Symposium in $1978, M$. Green commented that the discovery of wideworld appearance and the distribution of unstable sn-alleles «represented the first systematic tecovery of mutable genes in Drosophila and posed the novel question: what is the origin of unstable sn mutants?» [58].

As it is well known now, in 1977-78, mobile genetic elements (ME) were discovered in Drosophila independently by two groups of molecular geneticists in USA and Russia. The sn locus appeared to be the target for the now famous $P$ element. More than $50 \%$ of unstable sn alleles from natural populations appeared to be connected with $P$-insertion [54]. $P$-mediated unstable $s n$-alleles isolated from one or distant populations differed on their phenotype, rate and direction of mutation in germ in somatic cells.

Unstable sn alleles isolated at the same time from one population appeared to be connected with the insertion of different $M E$ (not only $P$ but also copia-like $M E$ ). So the conclusion is inevitable that the sn-mutation outburst is the result of the simultaneous activation of different mobile elements [54].

In Table 2 we summarised certain new phenomena of genetic variability discovered in our genetic studies of insertion mutations isolated 
from natural populations. Of special interest is the first described case of natural genetic engineering. Two separate genes «singed bristle» and «club wing» on the X-chromosome isolated from a Far Eastern population appeared to be joined under the control of one $M E$ capable of transposition (pressumably $m d g 3$ ). As a result of such engineering bimutant unstahle construction occurred $[5 \mathrm{l}, 52,112]$. This insertional bimulant construction was unstable and gave normal derivatives which once more reversed to the bimutant condition. Many of the genefic aspects of this new genetic construction mediated by transposon behaviour were clarified. The spectrum of ordered changes of this natural engineering construclion was thoroughly studied (Fig. 1).

We now need a wide presentation of sources and factors inducing genetic variability. It is evident that classical mutations make up only part of the genetic variability found in eukaryolic genomes. It was suggesied that the eukaryotic genome can be seen as a population of DNA and RN: self reduplicaling elements $[-5]$. It is then useful to make a further division. We suggested [48] a distrimination in the eutaryotic genome bolween the two subsystems: the OBLlGATE and the FACULTATIVE. We believe this subdivision is a nalural one. The obligate part includes the set of genetic loci conlained on chromosomes and in the DNA of cellular organelles. In classical genetics each geneic locus has a definite position on a genetic map. It is the skeleton of the genome. But the genome also includes different kinds of facultalive elcments, varying in number and cell topography. The DNA and RNA elemenis may vary in number and topography from cell 10 cell and from individual to indivi. dual. The facultative part of the genome includes the hierarchy of clements from highly repeated and satellite DNA to plasmids, B-chromosomes and certain (relatively stable) cytobionts present both in the nucleus and the cytoplasm.

This natural structural subdivision leads to the discrimination between changes within obligale elenctuls (changes of their structure, num-

Table 2

Genetir. variability events observed in experiments with insertional mutations extracted from natural populations

Level of organization $\mid$ Character of variability and genefic events

Genes and chromosomes

Individual (Developmental)

Population
Gene instability due to insertions of $P$ and other $M E$ s activated in natural populations [48].

Allele specific character of instability in germinal and somatic cells $[43,44,46]$.

Increased rate of mutations in X-chromosomes containing unstable sn-alleles [47].

Paramutation phenomenon in the progeny of heterozygotes on two unstable sn-alle]es [48].

Influence of homologous locus structure on the mutation rate of an insertional allele $[1] 3,1 / 4]$.

Recombination in heterozygotes on two insertional alleles is abnormal, it is induced by the excision of MEs and occurs premeiotically $[113,114]$

The complex control of insertional mutability: cytotype, mutator genes, interactions of MEs [52, 55, 108].

Clusters of mutants in the progeny of one individual with unstable alteles due to transpositions of $M E$ during the first zygotic divisions $[50,56]$.

Genetic engineering in ruture: two separate genes under the control of one ME are simultaneusly expressed and matate [112].

Expression of insertional mutation may depend on temperature and the Y-chromosome and is similar to position effect $[1 ; 15]$.

Synohronous outbursts of mutability and appearance of multiple insertional alieles in distant populations, *Mode of mutations* [62, 116].

Multisite mutations induced by viruses and foreign DNA can spread in natural populations [3]. 
ber and position) and changes within facultative elements. The first class of changes correspond to classical mutations. Various changes of different facultative elements may be called variations. Variations are the most frequent class of hereditary changes, because faculttive elements are quite susceptible to a wide spectrum of evironmental changes. Mutations or direct damage of genetic loci occur mainly after the strong

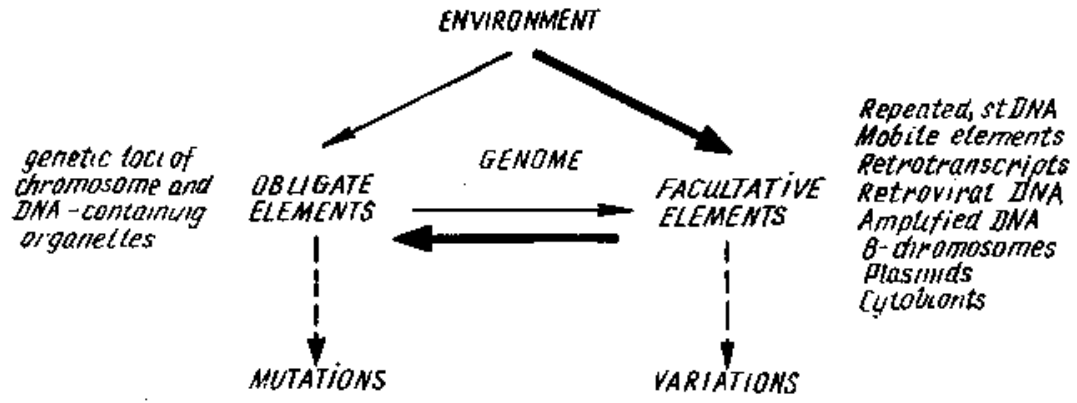

The thickness of the arrows indicate the magnitude of the influence

Fig. 2. Two types of genetic elements in the eukaryotic genomes and two types of genetic changes: mutations and variations

action of environmental factors (radiation, chemical mutagenes, defects in repair system et cetera). But the predominantly weak action of environmental factors (in a broad sense-physical, biotical and genetical) is received and reacted to initially by the set of facultative elements.

Thus interactions between the components of the system ENVIRONMENT - FACULTATIVE - OBLIGATE ELEMENTS is the major source of most genetical changes occurring de novo in nature. This scheme is shown in Fig. 2 where narrows indicate the nature of the links, and their width schematically correspond to their intensity or force. If mutations usually occur at a low frequency, unpredictable, variations may occur frequently and orderly.

The subsystem of the facultative elements is the first one which reacts to environmental changes. Many variations (changes in the number of high repeated or stDNA sequencies, changes in the number and topography of amplified sequencies and mobile elements, and the presence or absence of cytobionts) may have no visible or physiological effects detectable by usual genetic methods. At the same time such variations as the transposition of MEs may induce insertional mutations and rearrangernents of chromosomes with definite physiological consequences as sterility. Changes in the number of definite facultative elements, for instance the number of RNA containing sigma viruses in the cytoplasm may have such important physiological consequences as susceptibility to carbon dioxide. The observation and estimation of the frequency of variation-creation events needs a special selective system as in the case of MRfactors [57, 58], hybrid dysgenesis or, as in the case of transpositional bursts and concerted transpositions discovered by the Russian geneticists $[34,35,60,61]$.

In conclusion we would like to remind the reader that the direction of Russian population studies and Dobzhansky's work were often synchronous and parallelic. This fact is rooted both in the inner logic of science and that both their «foundation principles», originated from the same scientific schools.

Dobzhansky regularly exchanged letters with his Leningrad University student and friend Ju. Ja. Kerkis. At the same time he was keenly interested in population studies in Russia.

In one of his last letters, Dobzhansky discussing the puzzling phenomenon of synchronous fluctuations of mutability and the appearance of multiple series of unstable sn alleles in distant populations, remarked 
how wrong much of molecular geneticists thinking was in the 70 s. Population genetics to them seemed to be as exhausted field like a squeezed lemon, wrote Dobzhansky. Indeed the discovery of the fact that multiple instability in nature is connected with the activation of mobile elements marks the beginning the promising synthesis of molecular and population genetics.

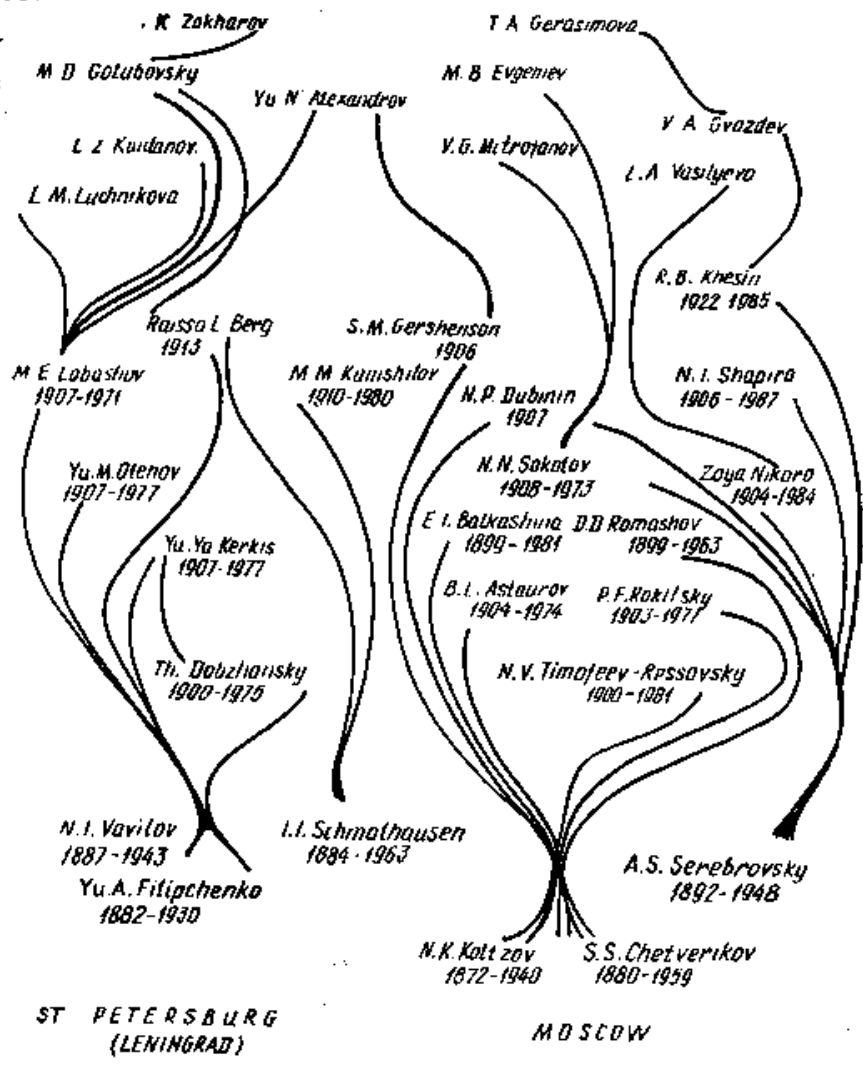

Sehoots

Acknowledgment. The authors are very grateful to Richard Newcomb for his comments and help in the preparation of this manuscript. We thank M. M. Green, John Gibson, A. Korol, C. Krimbas, A. Saura, Nadine Plus, $C$. Biemont and $J$. David for reading of the original version of the manuscript, critical remarks and advices.

\section{М. Голубовський, Л. Кайданов}

\section{ДОСЛІДЖЕННЯ ГЕНЕТИЧНОІ МІНЛИВОСТІ В ПОПУЛЯЦІЯХ ДРОЗОФІЛИ}

\section{Р ез но м}

Статтю прнсвячено історії виникнення та розвитку полуляційної i еволюційної генетики і тнх відкриттів, які було зроблено в експериментах на дрозофілі за період до 1948 p., а також опнсу реэультатів двох серій довготривалих досліджень генетичноі мінливості на дрозофілі, виконаних авторами. Розглянуто концептуальний $\mathrm{i}$ експернментальний внесок двох основних центрів, або шкіл, загальноі i лопуляційлої генетнки: московської (М. Қ. Қольцов і С. С. Четвериков) та петербурзької (Ю. О. Фнлил. ченко). Іх ідеї і методи були в подальшому інтродуковані до американської та європейської генетики Т. Добжанським і $M$. В. Тимофеевим-Ресовським.

Представлено нове розуміння організації геному еухаріот та новий тог.ця на природу спонтанних спадкових змін, виникаючих переважно внаслідок взаємодії середовнца з факультативними елементами геному. 


\section{REFERENCES}

1. Adams M. B. Severtsov and Schmalhausen: Russian morphology and evolutionary synthesis // The evolutionary synlhesis / Edz E. Mayr, W. B. Provine.-Cambridge: Harvard Univ. press, 1980a.- P. 193-225.

2. Adams M. B. Sergei Chetverikov, the Koltsov Inslitute, and the evolutionary synthesis // Ibid - 1980b. - P. 242-278.

3. Alexandrov $Y u$. $N$, Golubovsky $M$. $D$. The multisite mutations induced by viruses ant foreign DNA can spread in ratural populations of Drosophila // Drosophila Inf. Serv.-1983.-59- P. 10-12.

4. Auterson W., Dobzhansky Th., Pavlowsky O. et al. Genetics of natural populations. Three decades of genetic change in Drosophila pseudoobscura // Evolution.- 1975.29.- P. 24-36.

5. Bahkov V. V. Moscow school of evolutionary genetics-Moscow : Nauka, 1985.

6. Beig $R$. L. Difference in the frequency of occurence of the mutation yelliw ju ditferent populations of Drosophila melanogaster // Bull. Acad. Sci. USSR Birl. Ser.19.15- - i. - P $377-382$.

7. Berg R. L. Studies on mutability in geographically isolated populations of Dro. sriphila melanogaster // Mutat. in populations / Ed. R. Honcariv.- Prague: Chechissl. Acad. Sci., 1966.- P. 61-74.

8. Be" R. l. Genelic load as a possible basis of inherited immunity oi insects // 13 Jut. Congr, entomology.-Moscow, 1968. - P. 29.

9. Bers R. L. A sudden and synchronous increase in the frequency of «abmurmal abromens in geographically isolated populations of Drosophila melanogaster // Dros.ophila Inf. Serv-1972.- P. 48-94.

10. Berg R. L. A simultaneous mutability rise at the singed loctss in two ouf three Diosophila melanogasier populations studied in $1973 / /$ Ibid.-1974.-51. - P. $100-102$.

11. Berg R. L. Mutability changes in Drosophila melanogaster populations of Europe, Asia and North America and probable mutability changes in human populalions in the USSR // Jap. J. Genet.-1982.-57.- P. 171-183

12. Berg R. L., Brissenden E. B., Alexandriyskaya V. T., Galkovskaya K. F. Genetical allalysis of two wild populations of Drosophila melanogaster // Zhuru. General Bist. - 1941.-2, N 1.-P. 143-158.- (In Russian).

13. Berg R. L, Engels W. R, Kreber $R$. A. Sile specijic X-chromosome rearrangements irom hybrid dysgenesis in Drosophila melanogaster // Science.- 1980._210.P. 4. $72-429$.

14. Burisov A. I. Adaptive significance of chromosomal polymorphism. Comınu, 111. Firther evolution of the triban race of Drosophila funebris // Genetika.- 1969.5. N 5.-P, 119-122.

15. Campuzano S., Modolell J. Patterning the Drosophila neroous system: the achaete scute gene complex // Trends Genet. $-1992,-8$, N 6. - P. 202-208.

16. Chelierikov $S$. $S$. Ors several aspects of the evolut :onary process from the vicw p.ijlt of mijern genelics // Zhurn. Exp. Biol, ser. A.-1926.-2, N 1.-P. 3-54. (Iil Russian).

17. Chetverikov $S$. $S$. On certain aspects of the evolutionary process from the slanpoint of modern genetics // Proc. Amet. Phil. Soc.-1961 - 105.- P. 167-195.

18. Chetverikov S. S. Problems of general biology and genetics (Memoirs, articles, leclutes) / Ed. S. Zoya Nikoro.- Novosibirsk : Nauka, 1983.-272 p.

19. Dobzhansky Th. Evolutionary oscillations in Drosophila pseudoobscura // Ecological genelics and evolution / Ed. R. Creed.-Oxtord; Edinburg : Blackwell, 1971.P. $109-120$.

20. Dobzhansky $T h$. The birth of the genetic theory of evolution in the Soviet Union in the 1920s // The evolutionary synthesis / Eds E. Mayr, W. B. Provine.-Cambridge : Harv. Univ. press, 1980.- P. 229-242.

21. Dobzhansky Th., Queal $M$. L. Genetics of natural populations. 11. Genetic vartation in population of Drosophila pseudoobscura inhibiting isolated mountain regions // Geretics.-1938.-23.-P. 463-484.

22. Dubinin N. P. Genetic-automatic processes and their significance for the mechanism of organic evolution // Zhurn. Exp. Biol-- 1931.-7.-P. 463-479.- (In Russian).

23. Dubinin N. P. On lethal mutations in natura] populations // Genetics.- 1946.31.-P. 21-38.- (In Russian).

24. Dubinin N. P. Evolution of population and radiation.-Moscow: Atomizdat, 1966.-. 743 p.

25. Dubinin N. P., Geptner M. A., Nikoro Z. S. et al. Experimental analysis of ecogenotypes of Drosophila melanogaster. Pts 1 and $2 / /$ Biol. Zhurn.- 1934.-3, N 1.-P. 166-216.- (In Russian).

26. Dubinin N. P., Tinyakov G. G. Seasonal cycles and concentration of inversions in populations" of Drosophila funebris // Amer. Natur. $-1945 \ldots 79 . \ldots$ P. 570 -572.

27. Dubinin $N$. P., Tinyakov $G$. $G$. Inversion gradients and natural selection in ecological races of "Drosophila funebris // Genetics. - 1946.-31.- P. 537 -545.

28. Duseeva $N$. D. On the distribution of high mutability in populations of Drosophila melanogaster // Dokl. Akad. Nauk SSSR - 1948. - 55.-P. 865-870.

29. Evgentev $M . B$., Zelentsota $E$. S. Evolution of mobile dispersed genetic elements and satellite DNA in Drosophita // Citology and Genetics.-1984.-6.- P. 438442.- (In Russian). 
30. Filipchenko $Y_{u} . A$. Variation and methods of its study.-Petrograd : Gosizdat, 1923.

31. Filipchenko $Y u$. $A$. The evolutionary idea in biology.-Moscow : Izdat. Sabashnikovykh, 1926.

32. Gateff E., Schneiderman H. A. Developmental capacities of benign and malignant neoplasm of Drosophila // Wilhelm Roux's Arch. Dev. Biol.-1974.-176.P. $26-65$.

33. Gazaryan $K . G$, Nabirochkin $S . D$., Tatosyn $A$. G. et at. Genetic effects of injection of rous sarcoma virus DNA into polar plasm of early Drosophila melanogaster embryos // Nature. - 1984. - 311. - P. 392-394.

34. Gerasimova T. I, Mizrokhi L. Yu., Georgiev G. P. Transposition bursts in germ cells in Drosophila melanogaster // Ibid - -309... P. 714-716.

35. Gerasimova $T$. I., Matyunina $L . V$, Ityin $Y_{u}$. $V_{1}$, Georgiev $G$. $P$. Simultaneous transposition of different mobile elements: relation to multiple mutagenesis in Drosophila melanogaster // Mol. and Gen. Genet.-1984-194.- P. 517-522.

36. Gershenson $S$. M. Mutant genes in a wild population of Drosophila obscura // Amer. Natur. $-1934 .-68 .-8.569-580$.

37. Gershenson $S$. $M$. The character of mutations inducible in Drosophila by the sodium salt of thymonucleic acid // Dokl. Acad. Nauk SSSR-1940.-26.-P. 609.

38. Gershenson $S$. $M$. New data on the genetics of natural populations of Drosophila melanogaster // Memoires of Genetics. Inst. Zool. Acad. Sci. Ukr. SSR,- 1941._ 4/5.- P. 3-39.

39. Gershenson $S$. $M$. Viruses as environmental mutagenic factors // Mutat. Res.1986.- 167.-. P. $203-213$.

40. Gershenson S. M., Alexandrov Yu. N., Maliuta S. S. Mutagenic action of DNA and viruses in Drosophila.- Kiev : Naukova dumka, $1975 .-160 \mathrm{p}$.

41. Golubovsky $M$. D. Seasonal dynamics of the pool of lethal mutations in three neighbouring populations of Drosophila melanogaster // Genetika.-1970.-6, N 1.-P. $78-89$.

42. Golubousky M. D. Paramutation in Drosophila // Ibid.-m 1977,-13, N 9.P. 1605-1611.

43. Golubousky $M$. D. The comparison of direct and back mutations in germinal and somatic cells for three pairs of unstable singed allele in $D$. melanogaster // Drosophila Inf. Serv.-1978.-P. 116.

44. Golubovsky $M$. D. Two types of instability of singed alleles isolated from population of Drosophila melanogaster during mutation outburst in 1973 // Ibid.-P. 171 .

45. Golubovsky $M$. D. The klethal giant larvae the most frequent second chromosome lethal in natural populations of Drosophila melanogaster // Ibid.-P. 179.

46. Golubovsky $M . D$. Mutational process and microevolution // Genetica.- $1980 .-$ 52/53. - P. 139-149.

47. Golubovsky $M . D$. The increase of X-linked lethal and non-disfunction rates in genotypes with unstable singed alleles in $D$. melanogaster // Drosophila lnf. Serv.1983.- 59. - P. 40-41.

48. Golubovsky $M, D$. Organization of the genotype and forms of hereditary variability in eukaryotes // Ađv. Modern Biol.-1985.- 100, N 3(6).-P. 323-339.- (In Russian).

49. Golubovsky $M$. D., Ivanov Yu. N., Zakharov $1 . K$., Berg R. L. Investigation of synchronous and parallel changes in the getre pools in natural populations of the fruit fly Drosophila melanogaster // Genetika.-1974.-10, N 4.-P. 72-83.

50. Golubovsky M. D., Ivanov Yu. N., Green M. M. Genetic instability in Drosophila melanogaster: putative multiple insertion mutants at the singed bristle locus $\|$ Proc. Nat. Acad. Sci. USA.— 1977.-74, N 7.- P. 2973-2975.

51. Golubovsky $M . D$., Zakharov $J$. $K$. Combined teversions of two unstable genes in the X-chromosomes of Drosophila melanogaster // Geneties._1979,_15, N 9.P. $1599-1609$.

52. Golubovsky $M . D .$, Zakharov $I, K$. A mutator gene increasing frequency of reversions of a number of phenotypically normal unstable alleles of the singed locus in Drosophila melanogaster // Genetika,-1979.-15, N 10.-P. 1798-1808.

53. Golabovsky $M$. D., Plus $N$. Mutability studies in two Drosophila melanogaster isogenic stocks endemic for $\mathrm{C}$ picornavirus and virus free // Mutat. Res.-1982.N 1 . - P. $29-32$.

54. Golubovsky M. D., Belyaeva E. S. Outbreak of mutations in nature and mobile genetic elements: study of the series of alleles at the singed locus in Drosophila melanogaster // Genetika.- 1985.-21, N 10.-P. 1662-1670.

55. Golubousky $M$. D., Voloshina $M$. A., Zakharov 1. K., Yurchenko N. N. Interaction of the mobile elements $\mathrm{P}$ and $m d g 3$ in Drosophila melanogaster: genetic aspect $/ /$ Ibid.-1986.-22, N 10.-P. 2452-2458.

56. Golubovsky M. D., Zakharov I. K., Sokolova $O$. A. Instability of alleles at the yellow gene analyzed for a natural population of Drosophila melanogaster during mutability outburst // Ibid. - 1987, 23, N 9.- P. 1595-1603.

57. Green $M . M$. Genetic instability in Drosophila melanogaster: de novo induction of putative insertion mutations // Proc. Nat. Acad, Sci. USA-1977,-74.-P. 34903493.

58. Green M. M. The genetic control of mutation in Drosophila // Stadier Genet. Symp.-1978.- 10.-P. 95-104. 
59. Green M. M., Shepherd S. H. Y. Genetic instability in Drosophila melanogaster: the induction of specific chromosome 2 deletions by $M R$ elements // Genetics. 1979,-92.-P, 823-832.

60. Gvozdev V. A., Belyaeva E. S., Iyin $Y u$. V. et al. Selection and transposition of mobile dispersed genes in Drosophila melanogaster // Cold Spring Harbor Quant. Biol. $\rightarrow 1981 .-45 .-$ P. $673-685$.

61. Guozdev V. A., Kaidanot L. Z. Genome variation due to transpositions of mobile genetic elements and fitness in Drosophila melanogaster // Zhurn. General Biol.1986.- 47.-P. $51 \rightarrow 63 .-($ In Russian).

62. Ivanov $Y_{u}$. N., Golubovsky $M$. $D$. Increase of mutation rate and appearance of unstable alleles of the singed gene in natural populations of Drosophila melanogaster // Genetika.-1977.-13.-P. 655-665.

63. Kaidanov L. Z. The analysis of genetic consequencices of selection and inbreeding in Drosophila melanogaster // Genetica.- 1980-52/53.-P. 165-181.

64. Kaidanov L. $Z$. About adaptive significance of the rate of mutation process // Studies on Genetics.-Leningtad : Univ. press, 1981.-P. 100-112.

65. Kaidanov L. Z. Animal population genetics // Sov. Sci. Rev. F. Physiol. Gen. Biol. United Kingdom.- Harwood Acad. publ., 1989.-Vol. 3.-P. $201-256$.

66. Kaidanor L. Z. The rules of genetical alteration in Drosophila melanogaster inbred lines determined by selection // Arch. Sci. Biol. $\rightarrow 1990 .-42 .-$ P. 131-148.- (Belgrade).

67. Kaidanov L. Z., Genova $G$. K., Gorbunova $N$. Identification of mutants affecting fitness and accumulated in chromosome 2 of strain HA of Drosophila melanogaster // Studies on Genetics.- Leningrad : Univ press, 1979.- P. 54-62.

68. Kaidanoz L. Z., Bolshakov V. N., Tsygintsev P. N., Guozdev V. A. The sources of genetic variability in highly inbred long-term selected strains of Drosophila melanogaster // Genetica.-1991.-85.-- P. 73-78.

69. Kamshilov $M . M$. Selection in differing condition of character manifestation II Biol. Zhurn. - 1935.-4, N 6 . P. 1005-1028.- (In Russian).

70. Kamshilov M. M. Correlations and selection /I Zhurn. General Biol,-1941,-2, N 1.- P. 109-128.-(In Russian).

71. Kamshilov M. M. About selection to cold resistance // Ibid.-2.-P. 211-229.

72. Kerkis Ju. Ya. Development of gonads in hybrids between Drosophila melanogaster and Drosophila simulans // L., Exp. Zool.-1933.-66.-P. 477-509.-(Belgrade).

73. Kerkis Ju. Ya. Chromosome conjugation in hybrids between Drosophila simulans and Drosophila melanogaster // Amer. Nat.-1936.-70.-P. 81-96.

74. Khakhina L. N. Concepts of symbiogenesis. A hystorical and critical study of the research of Russian botanists.-New Haven; London: Yale Univ, press, 1992.

75. Khesin R. B. Genome inconstancy.-Moscow: Nauka, 1984- $472 \mathrm{p}$.

76. Kidwell $M$. $G$. Horizontal transfer of $\mathrm{P}$ elements and other short inverted repeat transposons // Genetica.-1992.-86.-P. 275-286.

77. Korochkin L. I. Molecular genetic mechanisms of tissue specific esterase isozymes and protein expression in Drosophila // Isozymes: Structure, function and use in biology and medicine,- New York : Wiley-Liss. Inc., 1990--P. 339-440.

78. Lim T. Intrachromosomal rearrangements mediated by hobo transposon in Drosophila melanogaster // Proc. Nat. Acad. Sci. USA.-1988.-85.- P. 9153-9157.

79. Luchnikova E. M., Inge-Vechtomov S. G., Ibragimov A. I, Levchenko A. B. The effect on metamorphosis and reproduction of Drosophila melanogaster of genetic changes in the synthesis of sterols by Saccharomyces cereviciae in a two species system: producerconsumer // Studies on genetics.-Leningrad : Univ. press, 1981.P. $54-65$,

80. Luchnikova E. M., Savitskii V. V., Inge-Vechtomov $S$. G. The effect of sterol deficit in the nutrition of Drosophila females on the rate of radiation induced embryonic mortality in their offspring // Vestnik Leningrad. Univ. Ser. Biol-1987.1.- P. 98-100.

81. Mazing R. A. Increased viability of lethal heterozygotes in Drosophita melanogaster // Dokl. Akad. Nauk USSR - 1938. - 20, N 2/3.-P. 173-176.

82. Mechler B. M., McGinnis W., Gehring W. J. Molecular cloning of lethal (2) giant larvae, a recessive oncogene of Drosophila melanogaster // EMBO J.— 1985.-4, N 6.- P. $1551-1557$.

83. Mitrofanov V. G. Modification of the dominance trait in the Drosophila virilis group // Genetika.-1969.-5, N 12,- P. 62-66.

84. Mitrofanov $V$. $G$. Genetic analysis of the maternal effect of the mutant trait puffed in the hybrids Drosophila virilis Sturt. XDrosophila littoralis Sokolov// Ibid.1975.-11, N 10- - P. 43-46.

85. Muretov G. D. Physiological mutations and variation in the gene composition of Drosophila melanogaster // Dokl. Akad. Nauk SSSR.1939.-24.-P. 481-486.

86. Otenov $Y_{a} . M$., Kharmarz $I . S$. Dynamics of the gene composition in the natural population of Drosophila melanogaster // Ibid. - 1938. - 19_-P. $409-414$.

87. Olenov Yu. M., Kharmarz I. S., Galkovskaya $K$. $F$, Muretov G. D. Factors shaping the gene composition of natural populations of Drosophila melanogaster // Ibid.1939 - $-24-$ P. $476-480$.

88. Paul D. B., Krimbas C. B. Nikolai V. Timofeev-Ressovsky // Sci. Amer-1992.2.-P. $64-71$. 
89. Plus N., Golubovsky M. D. Resistance of Drosophila C virus of fiften l(2)gl/Cy stocks carrying $1(2)$ gl lethals from different geographical origin // Genetika.1980.- 12.-P. 227-230,- (Belgrade).

90. Polanyi $M$. Personal knowledge-Chicago: Univ. press, 1962.

91. Provine $W . B$. Alfred Henry Sturtevant and crosses between Drosophila melanogaster and Drosophila simulans // Genetics.-1991.-129.-P. 1-5.

92. Rokitsky P. F. Genetic analysis of the number of thoraxic bristles in Drosophila melanogaster // Zhurn. Exp. Biol._-1927.-3, N 3/4.-P. 171-187.- (In Russian).

93. Romashow $D$. $D$. About the condition for equilibrium in populations // Jbid.- 1931 .7.-P. $442-454$.

94. Romashov D. D., Balkashina E. I. Materials on the genetics of Drosophila funebris, Pt. 1 // Ibid.-1929.-5, N 2.- P. 102-146.

95. Scharloo $W$. Developmental and physiological aspects of a reaction norm $/ / \mathrm{Bio}$ science. - 1989.-- 39, N 7.-P. 465-474.

96. Serebrovsky A. S. Genogeography and the gene fund of agricultural animals in the USSR // Sci. word.-1928.-9.-P. 3-22.-(In Russian).

97. Serebrousky A. S. The method and problems of genogeography // Congr. genet. selection and animal breeding.-1930.-Pt. 2.-P. $71-86 .-$ (In Russian).

98. Serebrovsky $A . S$. On the possibility of a new method for the control of insect pests // Zool. Zhurn,-1940.-19.-P. 618-630.-(In Russian).

99. Strunnikov V. A. The appearance of the compensation gene complex as a factor of heterosis // Zhurn. General Biol.-1974.-35.-P. 666-676.-(In Rusșian),

100. Sokolov N.N. Interaction between the nucleus and cytoplasm during distant hy bridization of animals.-Moskow : Izdat. Akad. nauk, 1959.

101. Sokolova $K$. B., Golubovsky $M . D$. Manifestation, interaction and population distribution of alleles at the \&giant larvae locus in Drosophila melanogaster // Genetika.- 1959.-15, N 2.- P. 233--243.

102. Sokolova $K . B$, Golubovsky $M$. D. Viability of heterozygotes for lethal alelles of the kgiant larvae» locus in Drosophila melanogaster at various temperatures $/ /$ Ibid - - 1979.-15, N 3.- P. 454-464.

103. Timofeev-Ressovsky N. V. About phenotypical manifestation of genotype, 1., Genovariation radius incompletus in Drosophila funebris // Zhurn. Exp. Biol. Ser. A.1925-1, N 3/4.-P. 93-i42.- (In Russian).

104. Timofeeva-Ressovskaya H. A., Timofeeff-Ressovsky N. W. Genetische Analyse einiger freilebenden Drosophila melanogaster Populationen // Roux'Arch. Entwicklungsmech. Organism.-1927.-109, N 1.-S. 70-109.

105. Tinofeeff-Ressovsky N. V. Uber den Einfluss des genotypishen Milieus und der Aussenbe dingungen auf Realisation des Genotyps. Genmutation vti (venae transversae incompletae) bei Drosophila funebris // Nachr. Ges. Wiss. Göttingen. Math.phys. KI. N. F.-1934.-1, N 6.-S. 53-106.

106. Timofeeff-Ressousky $N$. W' Uber die Vitalitát einiger Genmutationen und ihrèr Kombinationen bei Drosophila funebris und thre Abhangigkeit vom «genotypishen» und ausseren Milieu // Ztschr. Indukt. Abst. und Vererb.-- 1934.-66, N 3/4.S. $319-344$.

107. Tinyakov $G$. $G$. Highly mutable jine from the wild population of Drosophila melanogaster // Dokl. Akad. Nauk SSSR, - 1939, $\rightarrow 22,-$ P. 615-621.

108. Voloshina M. A., Golubovsky $M$. D. Genetic analysis of chromosomal and the cytoplasmic effect of the P-M system of hybrid dysgenesis on the instability of the mutations induced by insertions on the instability of the mutations induced by insertions of different mobile elements in Drosophila // Genetika.- 1986.- 22, N 4.-P. $624-632$.

109. Vorontsov N. N., Golubovsky $M, D$. Population and evolutionary genetics in the USSR in Vavilov's time / Ed. V. K. Shymnyi // Vavilov's heritage in modern biology.-Moscow : Nauka, 1989-P. 270-298.

110. Vucinich $A$. Darwin in Russian thought.-Berkely: Univ. of California press, 1988.

111. Whitten $M$. J. The conceptual basis for genetic control // Comprehensive insect physiol. biochem. and pharmacol.-Oxford; New York: Pergamon press, 1985.Vol. 12 - P. $466-528$.

112. Yurchenko $N . N$., Zakharov $I . K$, Golubovsky $M$. $D$. Unstable alleles of the singed locus in Drosophila melanogaster with reference to a transposon marked with a visible mutation // Mol. and Gen. Genet.-1984._- 194.-P. 279-285.

113. Yurchenko N. U., Zakharov I. K., Golubovsky M. D. Recombination in Drosophila mediated by a mobile element // Genetika.- 1985.-20, N 6.- P. 974-983.

114. Yurchenko N. N., Zakharov $I . K$, Golubovsky $M$. D. Effect of the structure of a homologous locus on the transposon behavior in Drosophila melanogaster // lbid.21, N 8.-P. $1290-1296$.

115. Zakharov $I$. K., Golubovsky $M$. D. The influence of temperature and $\mathrm{Y}$ chromosome on manifestation and frequency of simultaneous mutation of two unstable genes in Drosophila melanogaster // Ibid.-1980.-16, N 9.- P. 1603-1612.

116. Zakharov $I . K$., Goluboosky $M$. $D$. The series of unstable singed alieles from natural populations of Drosophila melanogaster: trends of mutation induction // Jbid - 1984,-20, N 7,- P. 1124-1127.

117. Zakharov I. K., Golubovsky $M$. D. Repeated bursts of mutation yellow in naturaf Drosophila melanogaster population in Uman // Ibid.-1985.-21, N 8.- P. 1298.

Petersburg State University

11.04 .94 